\title{
The role of infectious pathogens in exacerbation of chronic obstructive pulmonary disease in Dakahlia Governorate
}

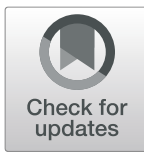

\author{
Elsayed Ahmed Fahmy ${ }^{1 *}$, Heba Wagih Abdelwahab ${ }^{1}$, Heba Elsayed Eldegla ${ }^{2}$ and \\ Mohammed Khairy Fahmy Elbadrawy ${ }^{1}$
}

\begin{abstract}
Background: Exacerbations of chronic obstructive pulmonary disease (COPD) represent important events in the management of COPD because of its negative impact on health status and disease progression. The etiology of acute exacerbations of chronic obstructive pulmonary disease (COPDAE) is heterogeneous and still under discussion. So, this study was planned to investigate the role of infectious pathogens (fungi and atypical mycobacteria in addition to the well-known bacteria) in patients with COPD exacerbation in our locality.

Results: This observational cross-sectional study was conducted on 100 patients with acute exacerbation of COPD. Sputum specimens were collected for mycobacterial and fungal examination in addition to routine sputum bacteriology. All sputum samples were negative for typical and atypical mycobacteria whereas sputum samples of 18 patients (18\%) were negative for fungi. Mixed fungal growth was found in 19 patients (19\%). Candida was isolated from 67 patients (67\%), Aspergillus was isolated from 27 patients (27\%), Alternaria was isolated from 3 patients (3\%), and other fungi were isolated from 4 patients (4\%). As regards sputum bacteriology, sputum samples of 49 patients (49\%) have bacterial growth. Streptococcus pneumoniae was isolated from 16 samples (16\%) and represents the most frequent bacterial isolate in this study.

Conclusion: The present study indicates that typical and atypical mycobacteria have no role in COPD exacerbations in our locality. However, fungi and bacteria may have a role in COPD exacerbations.
\end{abstract}

Keywords: COPD, COPD exacerbations, Atypical mycobacteria, Fungal infection

\section{Criteria of inclusion (target population)}

\section{The target population}

This study included 100 COPD patients diagnosed according to GOLD 2017 with acute exacerbation. Informed written consents were taken from all patients enrolled in the study after approval of our institutional research board under code (MD/17.02.88).

Patients who refused participation, or patients presented with other associated diseases such as bronchiectasis, history of tuberculosis, and bronchial carcinoma were excluded from the study.

\footnotetext{
* Correspondence: sayed.fahmy4444@gmail.com

${ }^{1}$ Chest Medicine Department, Mansoura University, Mansoura, Egypt

Full list of author information is available at the end of the article
}

\section{Location of the study}

This study was conducted at the Chest Medicine Department, Mansoura University Hospital, and Mansoura Chest Hospital over 24 months from May 2017 to May 2019 in collaboration with the Microbiology and Immunology Department, Mansoura University.

\section{Background}

Chronic obstructive pulmonary disease (COPD) is a common, preventable, and treatable disease that is characterized by persistent respiratory symptoms and airflow limitation [1]. Exacerbations are important events in COPD management because they negatively impact

\section{Springer Open}

(๑) The Author(s). 2020 Open Access This article is licensed under a Creative Commons Attribution 4.0 International License, which permits use, sharing, adaptation, distribution and reproduction in any medium or format, as long as you give appropriate credit to the original author(s) and the source, provide a link to the Creative Commons licence, and indicate if changes were made. The images or other third party material in this article are included in the article's Creative Commons licence, unless indicated otherwise in a credit line to the material. If material is not included in the article's Creative Commons licence and your intended use is not permitted by statutory regulation or exceeds the permitted use, you will need to obtain permission directly from the copyright holder. To view a copy of this licence, visit http://creativecommons.org/licenses/by/4.0/. 
health status, hospitalization rates, and disease progression [2].

Common bacterial organisms causing COPD exacerbation are Haemophilus influenzae, Streptococcus pneumoniae, Moraxella catarrhalis, and Pseudomonas aeruginosa [3].

Atypical mycobacteria are opportunistic bacteria and are therefore more likely to cause disease when there are defects in local or systemic host immunity and have potential to cause respiratory disease, particularly in patients with pre-existing lung damage [4]. Atypical mycobacterial colonization of the lower respiratory tract is an independent stimulus to airway inflammation and can modulate the character and frequency of COPD exacerbations [5]. The potential role of fungal infection in the pathogenesis of COPD is poorly understood [6].

So, this study was planned to investigate the role of infectious pathogens (fungi and atypical mycobacteria in addition to the well-known bacteria) in patients with COPD exacerbation in our locality.

\section{Methods}

\section{Study design}

This is an observational cross-sectional study.

\section{Duration of the study}

This study was conducted at our department, over 24 months from May 2017 to May 2019.

\section{The target population}

This study included 100 patients with acute exacerbations of chronic obstructive pulmonary disease (COPDAE) diagnosed according to GOLD 2017 [7]. They were included only if they had acute worsening of respiratory symptoms that require an additional therapy [7]. Exclusion criteria include patients who refused participation or patients presented with other associated diseases such as bronchiectasis, history of tuberculosis, and bronchial carcinoma. Patient selection bias was avoided by the clear definition of study population, using standardized protocol to collect data such as questionnaires as modified British Medical Research Council (mMRC), get information from two different sources as participant and participant's spouse, and implement blinding by being clueless about the disease status of studied participants. Sample size was determined by Epi Info program version 20. Informed written consents were taken from all patients enrolled in the study after approval of our institutional research board under code $(\mathrm{MD} / 17.02 .88)$.

\section{Data collected}

Clinical data

Full history taking and clinical examination were done with attention to age, sex, residence, occupation, smoking history, smoking index, severity of airflow limitation, severity of COPD, degree of exacerbation, medications used, and other comorbid diseases.

Spirometry was done for patients who were able to do the test and patients who were not able to do it; their spirometric measures were recorded from their hospital profile of previous admissions. Assessment of airflow limitation was according to GOLD 2017 [7] based on post-bronchodilator fixed ratio FEV1/FVC > 0.70: GOLD 1, FEV1 $\geq 80 \%$ predicted; GOLD 2, 50\% $>$ FEV1 > 80\% predicted; GOLD 3, 30\% > FEV1 > $50 \%$ predicted; and GOLD 4, FEV1 > 30\% predicted [7], severity of COPD according to GOLD 2017 (refined $\mathrm{ABCD}$ assessment tool).

COPD exacerbations are classified according to GOLD 2017 as follows: mild (treated with short acting bronchodilators only, SABDs), moderate (treated with SABDs plus antibiotics and/or oral corticosteroids), and severe (patient requires hospitalization or visits the emergency room). Severe exacerbations may also be associated with acute respiratory failure [7].

\section{Radiological data}

Chest X-ray was done for radiological assessment of the patients.

Sputum examination and culture for atypical mycobacteria, fungi, and other bacterial agents

Specimens were transported and processed immediately in the Microbiology Unit of our University. If delay was expected, specimens were preserved at refrigerator temperature $\left(4^{\circ} \mathrm{C}\right)$ for $24 \mathrm{~h}$ according to Mahon et al. [8].

\section{Microscopic examination of sputum}

\section{A. Gram staining}

Using a piece of stick, a purulent part of the sputum was transferred to a glass slide, and a thin smear was made, allowed to air-dry, heat fixed, and stained by the Gram technique .The Gram smear was examined also for the presence of predominant organisms among the pus cells [8].

\section{B. Ziehl-Neelsen staining to detect acid fast bacilli (AFB)}

To increase the chances of detecting AFB in sputum smears, the sputum was treated with $5 \%$ volume/volume sodium hypochlorite $(\mathrm{NaOC} 1)$, left for $10-15 \mathrm{~min}$ at 
room temperature followed by centrifugation at 250$1000 \mathrm{r} / \mathrm{min}$ for $20 \mathrm{~min}$. Then, the supernatant was discarded, and a drop of the well-mixed sediment was transferred to a clean scratch-free glass slide and it was spread to make a thin preparation and allowed to airdry. After dryness, the smear was heat-fixed and stained using the Ziehl-Neelsen technique and examined microscopically for AFB. The presence of thin, curved, single, pairs, or groups of pink bacilli that could be beaded on a blue background was reported as positive for AFB [9].

\section{Potassium hydroxide $(\mathrm{KOH})$ preparation to detect} Aspergillus spp. [10]

\section{Cultures of sputum}

A. Bacterial culture

The purulent part of the sputum was washed from saliva in about $5 \mathrm{ml}$ of sterile physiological saline [11]. Bacterial growth was identified systemically by the colony morphology, by Gram-stained film from the colonies examined for the characteristic morphology, and by biochemical reactions [12].

\section{B. Culture of sputum for Mycobacteria tuberculosis} (M. tuberculosis)

Sputum was decontaminated using sodium hydroxide, $40 \mathrm{~g} / \mathrm{l}$, before being cultured for $M$. tuberculosis. The Lowenstein-Jensen (LJ) egg medium was used for $M$. tuberculosis cultures. Decontaminated sputum was inoculated on LJ slopes and incubated aerobically at $35-37^{\circ} \mathrm{C}$ for 2-6 weeks. The organism is slowly growing. When cultured on the Lowenstein-Jensen medium at $30-35^{\circ} \mathrm{C}$, M. tuberculosis produces raised, dry, cream (buff) colored colonies. Visible colonies are usually produced $2-3$ weeks after incubation, but cultures should be incubated for up to 6 weeks before being discarded [8].

Non-tuberculous mycobacteria (NTM) can be differentiated from $M$. tuberculosis by their ability to produce pigment when cultured in darkness and light (scotochromogen), when only exposed to light (photochromogen) or non-pigment producing (nonchromogen), and by their ability to grow at $25^{\circ} \mathrm{C}$ and in 4 (p)-nitrobenzoic acid (PNB) medium. Most NTM, like M. tuberculosis, are slow-growing except Mycobacteria chelonae and Mycobacteria fortuitum which are rapid-growers [13]. Species identification in case of growth of NTM would be done by polymerase chain reaction-restriction fragment length polymorphism (PCR-RFLP). Choromosomal DNA of NTM isolates will be extracted using DNA extract kit according to the manufacturer's recommendations [14].

\section{Sputum culture for fungi}

For fungal isolation, sputum samples were plated on Sabouraud dextrose agar (SDA) containing $50 \mu \mathrm{g} / \mathrm{ml}$ chloramphenicol and incubated at 30 and $37^{\circ} \mathrm{C}$. Cultures were evaluated for growth every $24 \mathrm{~h}$ during the first 7 days and weekly till 28 days. If filamentous fungi were detected, colonies were cultured on potato dextrose agar and subcultures were incubated at 30,37 , and $42^{\circ} \mathrm{C}$ to identify the species [15].

Differentiation between commensals and pathogenic organisms in this study was done by isolation of the same organism from repeated cultures [16] which showed a pure growth of the same organism and confirmation by identification of the pathogenic forms of the organism on a direct film and correlation of our culture results with clinical, radiological, and laboratory findings of the patients [17].

\section{Statistical analysis}

Data were analyzed using Statistical Package for the Social Sciences (SPSS) statistical software (SPSS for windows v. 16.0). Categorical data were presented in the form of numbers and proportions. According to the results of normality tests, continuous data were presented either in the form of means and standard deviations or in the form of median (min-max) in case of non-normal distribution.

$T$ test was used to test significance in case of normal distribution, while the Mann-Whitney test was used in non-normally distributed data. Statistical significance was set at a level of $p<0.05$.

\section{Results}

One hundred patients with COPD exacerbations (mean age 62 years old) were enrolled. Only $10 \%$ of them were nonsmokers (Table 1). Sixty-three percent of studied patients were COPD group D. Degree of exacerbation in most of studied patients (53\%) was moderate and in about $37 \%$ was mild. Only $10 \%$ had severe exacerbation (Table 2).

As regards sputum bacteriology of studied patients, all sputum samples were negative for typical and atypical mycobacteria whereas bacterial culture revealed that Streptococcus pneumoniae was isolated from 16 patients (16\%), Klebseilla pneumoniae was isolated from $14 \mathrm{pa}-$ tients (14\%), Staphylococcus aureus was isolated from 9 patients (9\%), Pseudomonas spp. and Enterobacter spp. were isolated from 5 patients for each (5\%), Hemophilus influenzae was isolated from 3 patients (3\%), and Escherichia coli was isolated from 3 patients (3\%). However, normal flora (commensal flora) was isolated from 43 patients (43\%), no bacterial growth was found in 8 patients (8\%), and more than one organism was detected in 11 
Table 1 Sociodemographic characteristics of studied cases

\begin{tabular}{|c|c|c|c|}
\hline \multicolumn{2}{|c|}{ Age, mean $( \pm S D)$} & \multicolumn{2}{|l|}{$62( \pm 8)$} \\
\hline \multicolumn{2}{|c|}{ Smoking index (pack-year), median } & \multicolumn{2}{|l|}{39.4} \\
\hline & & Number & Percent (\%) \\
\hline \multirow[t]{2}{*}{ Sex } & Male & 98 & 98.0 \\
\hline & Female & 2 & 2.0 \\
\hline \multirow[t]{3}{*}{ Smoking } & Current & 46 & 46.0 \\
\hline & Ex-smoker & 44 & 44.0 \\
\hline & Nonsmokers & 10 & 10.0 \\
\hline \multirow[t]{3}{*}{ Smoking type } & Cigarette & 78 & 78.0 \\
\hline & Shisha & 6 & 6.0 \\
\hline & Both & 6 & 6.0 \\
\hline \multirow[t]{2}{*}{ Occupation } & Non-risky occupations & 64 & 64.0 \\
\hline & Risky occupations & 36 & 36.0 \\
\hline \multirow[t]{2}{*}{ Residence } & Urban & 62 & 62 \\
\hline & Rural & 38 & 38 \\
\hline
\end{tabular}

Risky occupations considered as risk factor for COPD, e.g., cafe workers, bakers, carpenters, agriculture workers, painters, diesel workers, and welding workers

patients (11\%). Also, there were no significant associations between the bacterial isolates and sociodemographic and clinical data of studied patients (Tables 3, 4, and 5).

As regards sputum examination for fungal growth, Candida was isolated from 67 patients (67\%),
Table 3 Isolated bacteria from sputum of studied cases

\begin{tabular}{lll}
\hline Bacterial culture & Number & Percent \\
\hline Klebsiella pneumoniae & 14 & 14.0 \\
Hemophilus influenzae & 3 & 3.0 \\
Staphylococcus aureus & 9 & 9.0 \\
Streptococcus pneumoniae & 16 & 16.0 \\
Pseudomonas aeruginosa & 5 & 5.0 \\
E. coli & 3 & 3.0 \\
Enterobacter spp. & 5 & 5.0 \\
Normal flora (commensals) & 43 & 43.0 \\
Other bacteria & 5 & 5.0 \\
No growth & 8 & 8.0 \\
More than one organism isolated & 11 & 11.0 \\
\hline
\end{tabular}

Bacteria are not mutually exclusive (overlapping). Other isolated bacteria include Proteous (1 case), Citrobacter (1 case), Acinetobacter (2 cases), and late lactose fermented bacteria (1 cases)

Aspergillus was isolated from 27 patients (27\%), Alternaria was isolated from 3 patients (3\%), and other fungi were isolated from 4 patients (4\%); no growth of fungi was found in 18 patients (18\%); and more than one fungus was found in 19 patients (19\%). Also, there were no significant associations between the fungal isolates and sociodemographic and clinical data of studied patients (Tables 6, 7, and 8).

Table 2 Clinical assessment of studied patients

\begin{tabular}{|c|c|c|c|}
\hline & & Number & Percent (\%) \\
\hline \multirow[t]{4}{*}{ Group (COPD severity) } & A & 13 & 13.0 \\
\hline & B & 16 & 16.0 \\
\hline & C & 8 & 8.0 \\
\hline & $\mathrm{D}$ & 63 & 63.0 \\
\hline \multirow[t]{4}{*}{ GOLD (severity of airway limitation) } & 1 & 12 & 12.0 \\
\hline & 2 & 41 & 41.0 \\
\hline & 3 & 25 & 25.0 \\
\hline & 4 & 20 & 20.0 \\
\hline \multirow[t]{3}{*}{ Exacerbation grade } & Mild & 37 & 37.0 \\
\hline & Moderate & 53 & 53.0 \\
\hline & Severe & 10 & 10.0 \\
\hline \multirow[t]{2}{*}{ Comorbid diseases } & Present & 67 & 67.0 \\
\hline & Absent & 33 & 33.0 \\
\hline \multicolumn{4}{|l|}{ Treatment } \\
\hline \multirow[t]{2}{*}{ Systemic steroids } & Not used & 98 & 98.0 \\
\hline & Used & 2 & 2.0 \\
\hline \multirow[t]{2}{*}{ Oxygen therapy } & Not used & 85 & 85.0 \\
\hline & Used & 15 & 15.0 \\
\hline \multirow[t]{2}{*}{ Non-invasive ventilation } & Not used & 97 & 97.0 \\
\hline & Used & 3 & 3.0 \\
\hline
\end{tabular}


Table 4 Isolated bacteria in association to sociodemographic data among the studied cases

\begin{tabular}{|c|c|c|c|c|c|}
\hline Parameter & & Total & $\begin{array}{l}\text { No growth/normal flora, } n(\%) \text {, } \\
51 \text { (51) }\end{array}$ & $\begin{array}{l}\text { Bacterial growth, } n(\%) \text {, } \\
49 \text { (49) }\end{array}$ & $\begin{array}{l}\text { Significance } \\
\text { ( } p \text { value) }\end{array}$ \\
\hline Age mean $( \pm S D)$ & & & $62.6 \pm 8.5$ & $62.5 \pm 7.6$ & $0.547^{d}$ \\
\hline \multirow[t]{2}{*}{ Sex, $n(\%)$} & Male & 98 & $50(51)$ & $48(49)$ & $1^{\mathrm{b}}$ \\
\hline & Female & 2 & $1(50)$ & $1(50)$ & \\
\hline \multirow[t]{2}{*}{ Occupation, n (\%) } & Non-risky & 64 & $30(46.9)$ & $34(53.1)$ & $.271^{\mathrm{a}}$ \\
\hline & Risky & 36 & $21(58.3)$ & $15(41.7)$ & \\
\hline \multirow[t]{2}{*}{ Residence, $n$ (\%) } & Urban & 62 & $31(50)$ & $31(50)$ & $.798^{\mathrm{a}}$ \\
\hline & Rural & 38 & $20(52.6)$ & $18(47.4)$ & \\
\hline \multirow[t]{3}{*}{ Smoking, $n$ (\%) } & Current smokers & 46 & $21(45.7)$ & $25(54.3)$ & $\mathrm{R}$ \\
\hline & Ex-smokers & 44 & $25(56.8)$ & $19(43.2)$ & $0.289^{\mathrm{a}}$ \\
\hline & Nonsmokers & 10 & $2(20)$ & $8(80)$ & $0.569^{a}$ \\
\hline \multirow[t]{4}{*}{ Smoking index (pack-year), n (\%) } & Median & Median & 40 & 45 & $.085^{c}$ \\
\hline & Range & $<40$ & $15(32.6)$ & $11(25)$ & \\
\hline & & $40-60$ & $18(39.1)$ & $17(38.6)$ & \\
\hline & & $>60$ & $13(28.3)$ & $16(36.4)$ & \\
\hline
\end{tabular}

Risky occupations considered as risk factor for COPD, e.g., cafe workers, bakers, carpenters, agriculture workers, painters, diesel workers, and welding workers $R$ reference class

${ }^{a}$ Chi-square

bFisher's exact

cMann-Whitney

${ }^{\mathrm{d}} T$ test

\section{Discussion}

Pathogenic bacteria are usually colonizing the airways of COPD patients, possibly contributing to increased airway inflammation, and have been implicated in COPD exacerbations (Lin et al. [18] and Erkan et al. [19]).
However, fungal and NTM colonization and their potential role in acute exacerbations of COPD are not widely investigated. This study is therefore designed to assess the role of infectious pathogens (fungi and atypical mycobacteria in addition to the well-known bacteria) in COPD exacerbations.

Table 5 Bacterial isolates in association to clinical and radiological data of studied cases

\begin{tabular}{|c|c|c|c|c|c|}
\hline Parameter & & Total & $\begin{array}{l}\text { No growth/normal flora, } \\
n(\%), 51(51)\end{array}$ & $\begin{array}{l}\text { Bacterial growth, } \\
n(\%), 49(49)\end{array}$ & Significance ( $p$ value) \\
\hline \multirow[t]{3}{*}{ Exacerbation grade, $n(\%)$} & Mild & 37 & $19(51.4)$ & $18(48.6)$ & $\mathrm{R}$ \\
\hline & Moderate & 53 & $27(50.9)$ & $26(49.1)$ & $0.97^{\mathrm{a}}$ \\
\hline & Severe & 10 & $5(50)$ & $5(50)$ & $0.94^{\mathrm{a}}$ \\
\hline \multirow[t]{4}{*}{ COPD groups, $n(\%)$} & A & 13 & $8(61.5)$ & $5(38.5)$ & $\mathrm{R}$ \\
\hline & B & 16 & $10(62.5)$ & $6(37.5)$ & $1^{\mathrm{a}}$ \\
\hline & $\mathrm{C}$ & 8 & $2(25)$ & $6(75)$ & $0.183^{\mathrm{a}}$ \\
\hline & D & 63 & $31(49.2)$ & $32(50.8)$ & $0.418^{\mathrm{a}}$ \\
\hline \multirow[t]{4}{*}{ GOLD (severity of airway limitation), $n(\%)$} & 1 & 12 & $8(66.7)$ & $4(33.3)$ & $\mathrm{R}$ \\
\hline & 2 & 41 & $20(48.8)$ & $21(51.2)$ & $0.275^{\mathrm{a}}$ \\
\hline & 3 & 25 & $12(48)$ & $13(52)$ & $0.386^{a}$ \\
\hline & 4 & 20 & $9(45)$ & $11(55)$ & $9.234^{\mathrm{a}}$ \\
\hline \multirow[t]{3}{*}{ X-ray, $n(\%)$} & Normal & 40 & $21(52.5)$ & $19(47.5)$ & $.918^{\mathrm{a}}$ \\
\hline & Hyperinflation & 49 & $24(49)$ & $25(51)$ & \\
\hline & Consolidation & 11 & $6(54.5)$ & $5(45.5)$ & \\
\hline
\end{tabular}


Table 6 Isolated fungi on cultures among the studied cases

\begin{tabular}{lll}
\hline Fungi & Number & Percent (\%) \\
\hline Candida & 67 & 67.0 \\
Aspergillus & 27 & 27.0 \\
Alternaria & 3 & 3.0 \\
Other fungi & 4 & 4.0 \\
No growth & 18 & 18.0 \\
More than one fungus isolated & 19 & 19.0
\end{tabular}

Fungi are not mutually exclusive (overlapping). Other isolated fungi include Trichosporon (1 case), mucormycosis (2 cases), and Basidiobalus (1 case)

Sputum samples were utilized for the diagnosis of the offending organisms for COPD exacerbation, as it is an easy method for sampling in spite of its drawbacks in diagnosis. In a study of Bafadhel et al. [20], they used sputum samples and PCR in the diagnosis of fungal isolates, while Guinea et al. [21] used sputum, BAL, bronchial aspirate, and transbronchial lung biopsy samples and serological tests in their study.

In this study, TB and atypical mycobacteria could not be isolated in all studied cases, either by $\mathrm{ZN}$ staining or by culture on the Lowenstein-Jensen medium. In a study by Huang et al. [22], they investigated the role of NTM in the clinical course and progression of COPD; their study was done in Taiwan and included 251 patients using Bactec technique in NTM isolation and excluded patients less than 40 years old, nonsmokers, and smokers with smoking index less than 10 pack-years. Char et al. [23] found that $11 \%$ of their patients had evidence of mycobacterial infection (TB and NTM), and their study was done in the UK and included 126 patients who underwent LVRS or bullectomy at the Royal Brompton Hospital from 2000 to 2013 and depended on pathological methods in diagnosis (necrotizing granuloma with or without positive ZN staining for acid fast bacilli). These differences may be attributed to utilization of other media such as Bactec method for NTM or TB isolation or pathological examination, disparities in patient selection criteria, study designs, epidemiological factors, environmental factors, and total number of studied patients.

The most common isolated bacteria in this study was Streptococcus pneumoniae (16\%), this is the same as that reported by Gupta et al. [24] as they isolated Streptococcus pneumoniae in $16 \%$ of their patients, and it is near to that reported by Sharma et al. [25] as they isolated Streptococcus pneumoniae in 13\% of their patients.

The second most common organism isolated from the sputum of our patients was Klebseilla pneumoniae, it was isolated from $14 \%$ of patients, and it is near to that reported by Lin et al. [18] as they reported that Klebseilla pneumoniae was isolated in $19.6 \%$ of sputum samples via aerobic cultures, but in a study by Bari et al.

Table 7 Fungal isolates in association to sociodemographic characteristics of studied patients

\begin{tabular}{|c|c|c|c|c|c|}
\hline Parameter & & Total & $\begin{array}{l}\text { No growth, } n(\%) \text {, } \\
18(18)\end{array}$ & $\begin{array}{l}\text { Fungal growth, } n(\%) \text {, } \\
82(82)\end{array}$ & $\begin{array}{l}\text { Significance } \\
\text { ( } p \text { value) }\end{array}$ \\
\hline Age, mean $( \pm S D)$ & & & $59.9 \pm 7.1$ & $63.1 \pm 8.2$ & $0.128^{d}$ \\
\hline \multirow[t]{2}{*}{ Sex, $n(\%)$} & Male & 98 & $18(18.4)$ & 80 (81.6) & $1^{b}$ \\
\hline & Female & 2 & $0(0)$ & $2(100)$ & \\
\hline \multirow[t]{2}{*}{ Occupation, $n(\%)$} & Non-risky & 64 & $9(14.1)$ & $55(85.9)$ & $0.172^{\mathrm{a}}$ \\
\hline & Risky & 36 & $9(25)$ & $27(75)$ & \\
\hline \multirow[t]{2}{*}{ Residence, $n(\%)$} & Urban & 62 & $7(11.3)$ & $55(88.7)$ & $.026^{\mathrm{a}}$ \\
\hline & Rural & 38 & $11(28.9)$ & $27(71.1)$ & \\
\hline \multirow[t]{3}{*}{ Smoking, $n(\%)$} & Current smokers & 46 & $6(13)$ & $40(87)$ & $\mathrm{R}$ \\
\hline & Ex-smokers & 44 & $10(22.7)$ & $34(77.3)$ & $.230^{\mathrm{a}}$ \\
\hline & Nonsmokers & 10 & $2(20)$ & $8(80)$ & $0.623^{\mathrm{a}}$ \\
\hline \multirow[t]{4}{*}{ Smoking index (pack-year), $n(\%)$} & Median & Median & 40 & 40 & $.830^{c}$ \\
\hline & Range & $<40$ & $8(50)$ & $22(29.8)$ & \\
\hline & & $40-60$ & $7(43.7)$ & $24(32.4)$ & \\
\hline & & $>60$ & $1(6.3)$ & $28(37.8)$ & \\
\hline
\end{tabular}

Risky occupations considered as risk factor for COPD, e.g., cafe workers, bakers, carpenters, agriculture workers, painters, diesel workers, and welding workers $R$ reference class

${ }^{a}$ Chi-square

${ }^{\mathrm{b}}$ Fisher's exact

'Mann-Whitney

${ }^{\mathrm{d}} T$ test 
Table 8 Fungal isolates in association to clinical and radiological data of studied patients

\begin{tabular}{|c|c|c|c|c|c|}
\hline Parameter & & Total & $\begin{array}{l}\text { No growth, } n(\%) \text {, } \\
18 \text { (18) }\end{array}$ & $\begin{array}{l}\text { Fungal growth, } n(\%) \text {, } \\
82(82)\end{array}$ & $\begin{array}{l}\text { Significance } \\
(p \text { value })\end{array}$ \\
\hline \multirow[t]{3}{*}{ Exacerbation grade, $n(\%)$} & Mild & 37 & $7(18.9)$ & $30(81.1)$ & R \\
\hline & Moderate & 53 & $10(18.9)$ & $43(81.1)$ & $0.995^{\mathrm{a}}$ \\
\hline & Severe & 10 & $1(10)$ & $9(90)$ & $0.667^{\mathrm{a}}$ \\
\hline \multirow[t]{4}{*}{ COPD groups, $n(\%)$} & A & 13 & $4(30.8)$ & $9(69.2)$ & $\mathrm{R}$ \\
\hline & B & 16 & $3(18.8)$ & $13(81.2)$ & $0.667^{a}$ \\
\hline & C & 8 & $0(0)$ & $8(100)$ & $0.131^{\mathrm{a}}$ \\
\hline & D & 63 & $11(17.5)$ & $52(82.5)$ & $0.273^{\mathrm{a}}$ \\
\hline \multirow{4}{*}{$\begin{array}{l}\text { GOLD (severity of airway } \\
\text { limitation), } n(\%)\end{array}$} & 1 & 12 & $3(25)$ & $9(75)$ & $\mathrm{R}$ \\
\hline & 2 & 41 & $2(4.9)$ & $39(95.1)$ & $0.07^{\mathrm{a}}$ \\
\hline & 3 & 25 & $6(24)$ & $19(76)$ & $1^{\mathrm{a}}$ \\
\hline & 4 & 20 & $6(30)$ & $14(70)$ & $1^{\mathrm{a}}$ \\
\hline \multirow[t]{2}{*}{ X-ray, $n(\%)$} & Normal & 40 & $7(17.5)$ & $33(82.5)$ & $1^{\mathrm{b}}$ \\
\hline & $\begin{array}{l}\text { Abnormal(hyperinflation and } \\
\text { consolidation) }\end{array}$ & 60 & $11(18.3)$ & $49(81.7)$ & \\
\hline \multirow[t]{2}{*}{ Comorbid diseases, $n(\%)$} & Present & 67 & $10(14.9)$ & $57(85.1)$ & $.254^{\mathrm{a}}$ \\
\hline & Absent & 33 & $8(24.2)$ & $25(75.8)$ & \\
\hline
\end{tabular}

Comorbid diseases: hypertension, ischemic heart diseases, renal impairment, chronic liver diseases, and heart failure

$R$ reference class

${ }^{\mathrm{a}}$ Chi-square

${ }^{\mathrm{b}}$ Fisher's exact

[26], they reported Klebsiella pneumoniae in $26 \%$ of their patients and Sharma et al. [25] in $6.3 \%$ of sputum samples via aerobic cultures.

The mean age of our patients with bacterial isolates was $62.5 \pm 7.6$ years, $49 \%$ were males, and the median of smoking index was 45 pack-years, while in a study of Papi et al. [27], they reported that the mean age of their patients was $70.6 \pm 2.5$ years, $87.5 \%$ were males, and the median of smoking index was $48.3 \pm 5.7$ pack-years. Bacterial isolates were associated in $48.6 \%$ of patients with mild exacerbation, $49.1 \%$ with moderate exacerbation, and $50 \%$ with severe exacerbation. In a study by Erkan et al. [19], they reported that COPD exacerbations increased by $88 \%$ with bacterial infection, while Sethi et al. [28] mentioned that bacterial isolates were associated with increase in the incidence of COPD exacerbation. As regards airway obstruction, bacterial isolates were associated in $33.3 \%$ of patients with mild airway obstruction, $51.2 \%$ with moderate obstruction, $52 \%$ with severe obstruction, and $55 \%$ with very severe obstruction, while Groenwegan and Wouters [29] reported bacterial isolates in $13 \%$ of patients with mild obstruction, in $32 \%$ of patients with moderate obstruction, and in $47 \%$ of patients with severe obstruction.

The most common fungal isolate in this study was Candida albicans that was isolated from $67 \%$ of patients, followed by Aspergillus that was isolated from $27 \%$ of patients and that is near to that reported by Mahmoud et al. [30], as they isolated Candida from $63.9 \%$ of their
COPD patients with acute exacerbation, followed by Aspergillus which was isolated in $36 \%$ of the patients in spite of their use of sputum, BAL, and serological tests in the diagnosis of fungal infections and their use of Sabaroud agar for fungal growth. The explanation of this relatively high rate of fungal growth may be attributed to association of patients with comorbid diseases and the frequent use of COPD patients to antibiotics and steroids.

The mean age of our patients with fungal isolates was $63.1 \pm 8.2$ years, $81.6 \%$ were males, and $85.1 \%$ of patients were associated with comorbid diseases, while Mahomoud et al. [30] reported that the mean age of their patients was $57 \pm 3.2$ years, $89.5 \%$ of patients were males, and the prevalence of fungal isolates was higher with comorbid diseases. Fungal isolates were associated with mild exacerbation in $81.1 \%$, moderate exacerbation in $81.1 \%$, and severe exacerbation in $90 \%$, while Mahmoud et al. [30] reported association of fungal isolates with mild exacerbation in $36.8 \%$, moderate exacerbation in $36.8 \%$, and severe exacerbation in $26.3 \%$. As regards airway obstruction, fungal isolates were associated with mild airway obstruction in $75 \%$, moderate obstruction in $95.1 \%$, severe obstruction in $76 \%$, and very severe obstruction in 70\%, while Mahmoud et al. [30] reported association of fungal isolates with moderate obstruction in $58 \%$ and severe obstruction in $42 \%$ and no fungal isolates were found in cases with very severe obstruction. However, in this study, there was no statistical 
significance in the association between the fungal isolates and sociodemographic and clinical data of studied patients.

There are limitations to this study. First, doing of extra tools for assessment of patients such as CT scan and using of other media for organism cultures and nonculture-based methods for fungal identification such as serological tests were limited due to the financial cost. Second, this study was done on hospital admitted patients that may represent high-risk patients with more comorbidities; consequently, the results may not be applicable to community-based settings. Third, fungal culture-based methods for organism identification had low sensitivity and low specificity and negative cultures cannot readily exclude fungal infection.

\section{Conclusion}

This study showed that fungal and bacterial isolates from the airway could have a role in COPD exacerbation. Non-tuberculous mycobacteria have no role in COPD exacerbation in our locality at the period from 2017 to 2019. These findings suggest that fungal, bacterial, and mycobacterial sputum cultures should be done for all patient of COPD exacerbation. Also, antifungal and antibacterial therapy should be considered in the treatment of COPD exacerbation, although the implication of this has not yet been conclusively established. Further investigations into the nature and consequences of the presence of NTM in COPD patients are required to confirm whether NTM have a role in COPD exacerbation or not.

\begin{abstract}
Abbreviations
AFB: Acid fast bacilli; BAL: Bronchoalveolar lavage; COPD: Chronic obstructive pulmonary disease; FEV1: Forced expiratory volume second 1; FVC: Forced vital capacity; GOLD: Global Initiative for Chronic Obstructive Lung Disease; HIV: Human immunodeficiency virus; $\mathrm{KOH}$ : Potassium hydroxide; L: Lowenstein-Jensen; M. tuberculosis: Mycobacteria tuberculosis: mMRC: Modified British Medical Research Council; NaOCI: Sodium hypochlorite; NTM: Non-tuberculous mycobacteria; PCR-PRFL: Polymerase chain reaction-restriction fragment length polymorphism; PNB: $\mathrm{p}$ Nitrobenzoic acid; SDA: Sabouraud dextrose agar; SPSS: Statistical Package for the Social Sciences; TB: Tuberculosis
\end{abstract}

\section{Acknowledgements}

Not applicable.

\section{Authors' contributions}

E.A.F. had selected the patients, collected the data and samples from patients, and wrote the research parts; H.W.A. had revised the research parts; H.E.E. did the microbiological work and revised the research; and M.K.F.E. had supervised all the research. All authors have read and approved the manuscript.

\section{Funding}

None.

Availability of data and materials Not applicable.
Ethics approval and consent to participate

Informed written consents were taken from all patients enrolled in the study after approval of our institutional research board under code (MD/17.02.88).

\section{Consent for publication}

Not applicable.

\section{Competing interests}

None.

\section{Author details}

${ }^{1}$ Chest Medicine Department, Mansoura University, Mansoura, Egypt.

${ }^{2}$ Microbiology and Immunology, Mansoura University, Mansoura, Egypt.

Received: 5 August 2020 Accepted: 21 October 2020

Published online: 04 November 2020

\section{References}

1. Vogelmeier CF, Criner GJ, Martinez FJ, Anzueto A, Barnes PJ, Bourbeau J, Frith P. (2017). Global strategy for the diagnosis, management, and prevention of chronic obstructive lung disease 2017 report. GOLD executive summary. Am J Respir Crit Care Med. 195(5):557-582.

2. Wedzicha JA, Seemungal TA (2007) COPD exacerbation: defining their cause and prevention. Lancet 370(9589):786-796

3. Sapey E, Stockley RA (2006) COPD exacerbations 2: aetiology. Thorax 61(3): 250-258

4. Glassroth J (2008) Pulmonary disease due to nontuberculous mycobacteria. Chest. 133:243-251

5. Patel AK, Luhadia AS, Luhadia SK (2014) Sputum bacteriology and antibiotic sensitivity pattern of patients having acute exacerbation of COPD in India: a preliminary study. J Pulm Respir Med. 5:1

6. Bulpa P, Dive A, Sibille Y (2007) Invasive pulmonary aspergillosis in patients with chronic obstructive pulmonary disease. Eur Respir J. 30(4):782-800

7. Singh D, Agusti A, Anzueto A, Barnes PJ, Bourbeau J, Celli BR, Varela MVL (2019). Global strategy for the diagnosis, management, and prevention of chronic obstructive lung disease: the GOLD science committee report 2019. Eur Respir J. 53(5)

8. Mahon CR, Lehman DC, Manuselis G (2014) Textbook of diagnostic microbiology (5th ed.). Saunders, New York

9. Murray PR, Baron EJ, Jorgensen JH, Pfaller MA, Yolken RH (2003) Manual of clinical microbiology, 8th edn. ASM Press, Washington, DC, USA

10. Gupta AK, Drummond-Main C, Cooper EA, Brintnell W, Piraccini BM, Tosti A (2012) Systematic review of nondermatophyte mold onychomycosis: diagnosis, clinical types, epidemiology, and treatment. J Am Acad Dermatol. 66(3):494-502

11. Lagier JC, Edouard S, Pagnier I, Mediannikov O, Drancourt M, Raoult D (2015) Current and past strategies for bacterial culture in clinical microbiology. Clin Microbiol Rev 28(1):208-236

12. Moyes RB, Reynolds J, Breakwell DP (2009) Differential staining of bacteria: gram stain. Curre Protocols Microbiol 15(1):A-3C

13. Cook VJ, Turenne CY, Wolfe J, Pauls R, Kabani A (2003) Conventional methods versus 165 ribosomal DNA sequencing for identification of nontuberculous mycobacteria: cost analysis. J Clin Microbiol 41(3):10101015

14. Saifi M, Jabbarzadeh E, Bahrmand AR, Karimi A, Pourazar S, Fateh A, Masoumi M, Vahidi E (2013) HSP65-PRA identification of non-tuberculosis mycobacteria from 4892 samples suspicious for mycobacterial infections. Clin Microbiol Infect 19(8):723-728

15. Máiz L, Girón R, Olveira C, Vendrell M, Nieto R, Martínez-García MA (2015) Prevalence and factors associated with isolation of Aspergillus and Candida from sputum in patients with non-cystic Fibrosis bronchiectasis. Respiration 89:396-403. https://doi.org/10.1159/000381289

16. Zhang H, Zhu A (2020) Emerging invasive fungal infections: clinical features and controversies in diagnosis and treatment processes. Infect Drug Resistance 13:607

17. Donnelly JP, Chen SC, Kauffman CA, Steinbach WJ, Baddley JW, Verweij PE, Sorrell TC (2019) Revision and update of the consensus definitions of invasive fungal disease from the European Organization for Research and Treatment of Cancer and the Mycoses Study Group Education and Research Consortium. Clin Infect Dis 71(6):1367-1376 
18. Lin SH, Kuo PH, Hsueh PR, Yang PC, Kuo SH (2007) Sputum bacteriology in hospitalized patients with acute exacerbation of chronic obstructive pulmonary disease in Taiwan with an emphasis on Klebsiella pneumoniae and Pseudomonas aeruginosa. Respirology. 12(1):81-87

19. Erkan L, Uzun O, Findik S, Katar D, Sanic A, Atici AG (2008) Role of bacteria in acute exacerbations of chronic obstructive pulmonary disease. Int J Chronic Obstruct Pulmon Dis. 3(3):463

20. Bafadhel M, Mckenna S, Agbetile J, Fairs A, Desai D, Mistry Pashley CH (2014) Aspergillus fumigatus during stable state and exacerbations of COPD. Eur Respir J 43(1):64-71

21. Guinea J, Torres-Narbona M, Gijón P, Muãoz P, Pozo F, Peláez T (2010) Pulmonary aspergillosis in patients with chronic obstructive pulmonary disease: incidence, risk factors, and outcome. Clin Microbiol Infect 16:870877

22. Huang CT, Tsai YJ, Wu HD, Wang JY, Yu CJ, Lee LN, Yang PC (2012) Impact of non-tuberculous mycobacteria on pulmonary function decline in chronic obstructive pulmonary disease. Int J Tuberculosis Lung Dis. 16(4):539-545

23. Char A, Hopkinson NS, Hansell DM, Nicholson AG, Shaw EC, Clark SJ, Loebinger MR (2014) Evidence of mycobacterial disease in COPD patients with lung volume reduction surgery; the importance of histological assessment of specimens: a cohort study. BMC Pulmon Med 14(1):124

24. Gupta R, Kaur R, Singh V, Goyal V, Dahiya K, Gupta A, Kumawat M (2012) Serial estimation of serum CRP levels in patients of COPD with acute exacerbation. Gobal J Med Public Health 1(6):1-10

25. Sharma P, Narula S, Sharma K, Kumar N, Lohchab K, Kumar N (2017) Sputum bacteriology and antibiotic sensitivity pattern in COPD exacerbation in India. Egypt J Chest Dis Tuberculosis 66(4):593-597

26. Bari MR, Hiron MM, Zaman SM, Rahman MM, Ganguly KC (2010) Microbes responsible for acute exacerbation of COPD. Mymensingh Med J 19(4):576585

27. Papi A, Bellettato CM, Braccioni $F$ (2006) Infections and airway inflammation in chronic obstructive pulmonary disease severe exacerbations. Am J Respir Crit Care Med 173(10):1114-1121

28. Sethi S, Evans N, Grant BJ, Murphy TF (2002) New strains of bacteria and exacerbations of chronic obstructive pulmonary disease. N Engl J Med. 347: 465-471

29. Groenewegen $\mathrm{KH}$, Wouters EF (2003) Bacterial infections in patients requiring admission for an acute exacerbation of COPD; a 1-year prospective study. Respir Med 97(7):770-777

30. Mahmoud EM, El-Din MMG, Hafez MR, Sobh E, Ibrahim RS (2019) Pulmonary fungal infection in patients with acute exacerbation of chronic obstructive pulmonary disease. Sci J Al-Azhar Med Faculty Girls 3(1):7

\section{Publisher's Note}

Springer Nature remains neutral with regard to jurisdictional claims in published maps and institutional affiliations.

\section{Submit your manuscript to a SpringerOpen ${ }^{\circ}$ journal and benefit from:}

- Convenient online submission

- Rigorous peer review

- Open access: articles freely available online

- High visibility within the field

- Retaining the copyright to your article

Submit your next manuscript at $\boldsymbol{\nabla}$ springeropen.com 